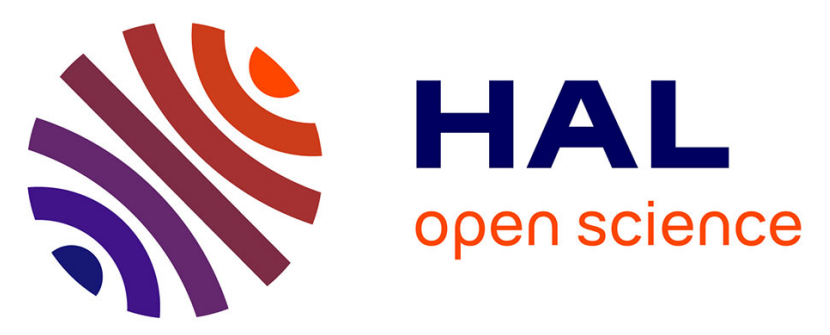

\title{
High-frequency monitoring of phytoplankton dynamics within the European water framework directive: application to metalimnetic cyanobacteria
}

B. Le Vu, Brigitte Vinçon-Leite, Bruno J. Lemaire, Nathaniel Bensoussan, M. Calzas, C. Drezen, José-Frédéric Deroubaix, Nicolas Escoffier, Yves Degres, C. Freissinet, et al.

\section{To cite this version:}

B. Le Vu, Brigitte Vinçon-Leite, Bruno J. Lemaire, Nathaniel Bensoussan, M. Calzas, et al.. Highfrequency monitoring of phytoplankton dynamics within the European water framework directive: application to metalimnetic cyanobacteria. Biogeochemistry, 2011, 106 (2), pp.229-242. 10.1007/s10533010-9446-1 . bioemco-00642853

\section{HAL Id: bioemco-00642853 \\ https://hal-bioemco.ccsd.cnrs.fr/bioemco-00642853}

Submitted on 19 Jun 2018

HAL is a multi-disciplinary open access archive for the deposit and dissemination of scientific research documents, whether they are published or not. The documents may come from teaching and research institutions in France or abroad, or from public or private research centers.
L'archive ouverte pluridisciplinaire HAL, est destinée au dépôt et à la diffusion de documents scientifiques de niveau recherche, publiés ou non, émanant des établissements d'enseignement et de recherche français ou étrangers, des laboratoires publics ou privés. 


\section{High-Frequency Monitoring of Phytoplankton Dynamics within the European Water Framework Directive: Application to Metalimnetic Cyanobacteria}

Le Vu B.(1), Vinçon-Leite B.(1), Lemaire B.J.(1), Bensoussan N.(2), Calzas M.(3), Drezen C.(3), Deroubaix J.F.(1), Escoffier N.(4), Dégrés Y.(7), Freissinet C.(9), Groleau A.(2), Humbert J.F.(4, 5), Paolini G.(8), Prévot F.(2), Quiblier C.(6), Rioust E.(1) and Tassin B.(1).

1. Université Paris-Est, UMR MA-102, LEESU, AgroParisTech, Ecole des Ponts ParisTech, F-77455 Marne-la-Vallée, France

2. IPGP, UMR 7154, Université Paris Diderot - Paris 7, Laboratoire de Géochimie des Eaux, F-75205 Paris Cedex 13, France

3. CNRS DT-INSU, Bâtiment IPEV, F-29280 Plouzané, France

4. Institut Pasteur, Unité des Cyanobactéries, F-75724 Paris, France

5. INRA, UMR CARRTEL, F-74203 Thonon-les-Bains, France

6. Muséum National d'Histoire Naturelle, Equipe SEM, F-75231 Paris, France

7. nke electronics, ZI de Kerandré, F-56700 Hennebont, France

8. CISALB, F-73000 Chambéry, France

9. SOGREAH, Division LHF, F-38130 Echirolles, France

Full address for correspondence, including telephone, fax number and e-mail address: Brigitte Vinçon-Leite, LEESU, Ecole des Ponts ParisTech, 6-8 Avenue Blaise Pascal, 77455 Marne la Vallée Cedex 2, France. (+33)164153642 (+33)164153766 bvl@cereve.enpc.fr

This article was published as Le Vu, B., Vinçon-Leite, B., Lemaire, B.J. et al. Biogeochemistry (2011) 106: 229. DOI:10.1007/s10533-010-9446-1

Key words: monitoring, stratified lakes, time series, WFD, cyanobacteria, phytoplankton, metalimnetic fluorescence peak

\footnotetext{
Abstract

Large, sub-alpine, stratified lakes are directly within the scope of the European Water Framework Directive (WFD) and need adapted monitoring systems. Moreover, anthropogenic eutrophication was frequently the main cause of their water quality degradation in the 20th century. This paper is primarily aimed at demonstrating how in situ sensor-equipped buoys could be the base of monitoring designs to support the WFD objectives. The core of this paper, mainly methodological, focuses on single-depth, high frequency ( 4 per hour) fluorescence measurements. It shows that the internal wave pattern provides additional information to the single-depth time series to assess phytoplankton dynamics in a stratified water column displaying strong, vertical biomass heterogeneity. The paper deals with the following three aspects: (1) definition of an indicator to determine whether or not the sensor actually detects the metalimnetic fluorescence peak, (2) vertical representation of chlorophyll distribution from single-depth series; (3) time evolution of the fluorescence peak (maximum value, depth and associated temperature, peak width).
} 


\section{Context and Objectives}

Anthropogenic eutrophication was the main cause of the deterioration of the water quality in European sub-alpine lakes in the 20 ${ }^{\text {th }}$ century; (Jeppesen et al., 2005; Gerdeaux et al., 2006; Salmaso et al., 2006; Tilzer et al., 1991; Vinçon-Leite et al., 1995a), in Italy (e.g. Great Lakes), Switzerland (e.g. Lake Geneva), Germany (e.g. Lake Constance), France (e.g. Lakes Bourget and Annecy), Austria (e.g. Mondsee). In spite of exhaustive restoration works in their watersheds (e.g. improved sewage treatment, ring trunk sewer, reduced use of detergent phosphorus), eutrophication control remains an issue for many sub-alpine lakes, for example Lake Geneva (Tadonléké et al., 2009), Lake Garda (Salmaso, 2009) or Lake Bourget (Jacquet et al.,2005), where phytoplankton biomass remains high or cyanobacteria proliferations regularly occur.

Phytoplankton blooms, triggered by nutrient loading which may be discharged by urban drainage systems, industry or agriculture are a major threat for lakes. Among the phytoplankton classes, cyanobacteria, which aggregate into dense biomass piles and surface scum, are specifically targeted, since some species produce toxins which can cause animal as well as human illnesses (Chorus and Bartram, 1999; Oberholster et al., 2006). Moreover, algal blooms in freshwater are frequently dominated by cyanobacteria (e.g. Dokulil and Teubner, 2000; Hudnell, 2009).

Sub-alpine lakes share common morphological features. They are narrow and elongated, with steep sides and generally a flat bottom; their thalwegs are roughly oriented north-south (Salmaso et al., 2006). Internal waves or seiches are commonplace during the summer stratification period.

To these common morphological features often correspond similar phytoplankton assemblages (Anneville et al., 2005). Cyanobacterium Planktothrix rubescens is frequently found in most of them (Briand et al., 2005; Ernst et al., 2009): e.g. Lake Zürich (Holland and Walsby, 2008; Walsby, 2006; Walsby and Schanz, 2002), Lake Garda (Salmaso et al., 2006), Lake Nantua (Feuillade and Orand, 1994; Jann-Para et al., 2004), Mondsee (Dokulil and Teubner, 2000). The microcystin-producing Planktothrix spp. is one of the most abundant genera amongst the widespread toxin-producing cyanobacteria in temperate climates (Ernst et al., 2006).

Large, sub-alpine lakes located in densely urbanized watersheds have essential functions for the city dwellers. Therefore, they are directly within the scope of the European Water Framework Directive and need adapted monitoring systems.

In the European Union, surface and groundwater aquatic systems are monitored and controlled according to directive 2000/60/EC (European Parliament and Council, 2000), also known as the Water Framework Directive (WFD).

The monitoring programmes described in the WFD have two objectives: to assess the ecological status of natural and artificial lakes inside homogeneous hydroecoregions and to survey the effect of restoration measures. Therefore, the three types of monitoring programmes (surveillance, operational, investigative monitoring programmes) described in the WFD vary in scope in time, space, and the quality elements which are monitored (WFD, Annex V; Ferreira et al., 2007).

The surveillance monitoring on a network of reference sites provides a panorama of the general status of aquatic ecosystems across the European Union. It also has the objective of assessing long-term changes in natural conditions, and long-term changes resulting from widespread anthropogenic activity (Ferreira et al., 2007).

Operational monitoring is performed on lakes which undergo restoration programmes called programmes of measures or which may fail to meet the environmental objectives of the WFD (good ecological status or potential); their status, as well as the effects of the programmes of measures, is to be assessed.

To understand the cause of the lake deterioration or in the case of accidental pollution, a more reinforced control called investigative monitoring is carried out. 
Phytoplankton is a key biological quality element for the establishment of the WFD ecological status in lakes: the composition, abundance and biomass of phytoplankton as well as the frequency and intensity of phytoplankton blooms are to be monitored. The commitment of monitoring phytoplankton blooms in numerous lakes requires reliable, cost-effective, easy-to-handle, monitoring systems (Allan et al., 2006; Dworak et al., 2005). But the traditional inverted microscope examination of phytoplankton abundance and taxonomic composition (AFNOR, 2006) is cumbersome, time-consuming, and requires highly qualified personnel. Moreover, the sampling frequency must be complying with the relevant timescales of the dynamics of the phytoplankton communities, and this is really unaffordable for water masses with these traditional methods. Available methods based on the composition of phytoplankton assemblages and the abundance ratios of the main phytoplankton classes could be an alternative to sampling and phytoplankton counting (Sarmento and Descy, 2008). These methods, allegedly, do not meet the requirements of the WFD to take into account the taxonomic composition and the frequency of algal blooms. But it can be regarded as a restrictive interpretation of the WFD which stipulates that "Member States shall identify the appropriate taxonomic level required to achieve adequate confidence and precision in the classification of the quality elements" (WFD, annex V, §1.3).

For all monitoring programmes required by the WFD, high-frequency monitoring systems may be useful, since episodic measurements may not enable the understanding of the local determinants of ecosystem dynamics (Carstensen, 2007; Kaiblinger et al., 2009).

Amongst autonomous monitoring systems, satellite remote sensing entails different limitations: some blooms can be too localised to be detected, but above all, satellite detection is limited by clouds and to the water surface only, while a lake's vertical structure drives phytoplankton dynamics. Therefore, in situ monitoring stations remain necessary.

In situ autonomous monitoring stations offer further advantages: (1) for surveying remote sites (polar (Palethorpe et al., 2004) or mountain lakes in particular); (2) for dealing with the scarcity of qualified personnel to perform sampling, chemical analysis and phytoplankton counting, (3) for reducing the cost due to repeated analyses. But there also limitations such as, for example the frequent field visits which are required for sensor maintenance and for data quality control. Moreover, difficulties can also appear from mismatch between concurrent on-site measurements and sensor time-series, collected during the same period (e.g. Garel et al., 2009; Vandenberghe et al.,2005).

In coastal waters, real-time monitoring systems have already been operating for some years: automated buoys developed for survey programme of coastal seas (Mills et al., 2003), phytoplankton bloom warning buoys for mariculture (Lee et al., 2005), warning system for low sub surface oxygen events (Bergondo et al., 2005), ®MAREL ${ }^{1}$ environmental monitoring buoys (Blain et al., 2004); (Dur et al., 2007). These systems are still rare in freshwater bodies and are mainly dedicated to research purposes (Jones and Maberly, 2008; Madgwick et al., 2006).

In this context, the primary objective of this paper is to demonstrate how in situ sensor-equipped buoys are valuable and consistent devices which can be incorporated into future monitoring designs to

\footnotetext{
${ }^{1}$ The ${ }^{\circledR}$ MAREL buoy (Mesures Automatisées en Réseau pour l'Environnement et le Littoral) is an automatic measurement system developed by IFREMER (French Research Institute for Exploitation of the Sea) for operational monitoring of coastal water quality.
} 
complete the WFD objectives. The core of this paper, mainly methodological, will focus on temperature and fluorescence measurements. It will show that the internal wave pattern can provide additional information to single-depth measurements: (1) an indicator determining whether the sensors detect the metalimnetic fluorescence maximum (fluorescence peak); (2) a vertical representation of fluorescence distribution from single-depth series; (3) the time evolution of the fluorescence peak (maximum value, depth and associated temperature, peak width).

The results presented in this paper have been established within the PROLIPHYC project. Since 2007 the PROLIPHYC consortium ${ }^{2}$ has been developing, validating and pre-industrializing a real-time, autonomous, monitoring buoy and a short-time forecasting and warning system for phytoplankton blooms, including cyanobacteria. The system is specifically adapted for lake stakeholders (drinking water producers, local health authority, etc.)

\section{Material and methods}

\subsection{Study site}

Lake Bourget (Figure 1) is a deep, well-stratified lake, located in the French Alps ( $231 \mathrm{~m}$ altitude) and can be seen as a representative study site for deep sub-alpine lakes. Lake Bourget is long $(18 \mathrm{~km})$, narrow $(2.5 \mathrm{~km})$ and deep (maximum depth $145 \mathrm{~m}$, mean depth $80 \mathrm{~m}$ ). The lake watershed contains an overall population of about 180000 inhabitants (INSEE, 2008), the largest towns being Chambéry (57 800 inh.) and Aix-les-Bains (27 500 inh.). The wastewater production in the watershed corresponds to 410000 population equivalent (Paolini, 2006) and is responsible for major anthropogenic impacts on the lake. Despite this considerable reduction of the nutrient concentrations since the eighties due to the improvement of waste water treatment and to the diversion of the treated effluent by a ring sewer, algal biomass remains high and the proliferations of the cyanobacterium, Planktothrix rubescens, which have been occurring regularly since 1996 impair the use of the lake for water supply and recreational activities. Furthermore, Lake Bourget is one of the most regularly monitored lakes in France; research projects concerning its main functioning features have been conducted for many years (e.g. (Groleau et al., 2000; Dorigo et al., 2006; Vinçon-Leite et al., 2002).

Since 1996, cyanobacteria have been regularly observed (CEREVE et al., 1998; Humbert et al., 2000; Oberhaus et al., 2003). The prevailing species, Planktothrix rubescens, can develop into a very high biomass, 100000 cell. $\mathrm{mL}^{-1}$ in August 2007. This stratifying species occupies the metalimnion at around $15 \mathrm{~m}$ in depth, from summer to autumn. In late autumn and winter, when the lake's upper layer mixes, its biomass can remain high.

${ }^{2}$ The PROLIPHYC project is conducted by a joint team of public research laboratories (Cereve, INRA, LGE, MNHN), the INSU-CNRS technical department (DT-INSU), an environmental engineering company (Sogreah), a water instrumentation company (nke) and a local authority (CISALB). 


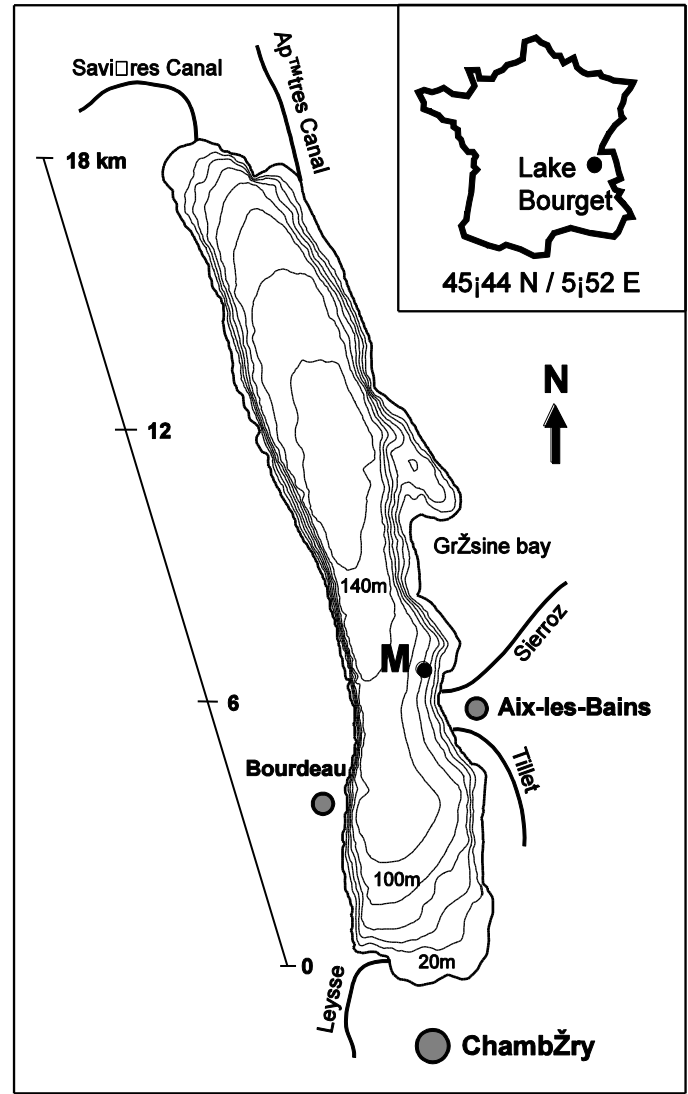

Figure 1: Lake Bourget aerial view and the buoy position (M point)

A warning system, based on a fortnightly survey, at the lake's mid-point, has been in operation since 1999. The vertical distribution in the water column of temperature and chlorophyll- $a$, distributed into phytoplankton classes, are measured using a thermistance and a 5-wavelength fluorometer (http://www.bbe-moldaenke.de). In Lake Bourget, Planktothrix rubescens cellular quota of microcystinLR is around 0.2 pg.cell ${ }^{-1}$ during the stratified season (Humbert et al., 2000; Briand et al., 2005). Therefore, the stakeholders are warned when the cyanobacteria concentration reaches 5000 cell. $\mathrm{mL}^{-1}$, which corresponds to a microcystin-LR concentration higher than $1 \mu \mathrm{g} . \mathrm{L}^{-1}$, threshold defined by the World Health Organisation (Chorus and Bartram 1999). The local authorities are very committed to the development of a more reliable and more economic monitoring system for the lake.

\subsection{Internal waves in Lake Bourget}

Internal waves or seiches are frequently observed in lakes where a thermal stratification of the water column occurs (e.g. (Lemmin and Mortimer, 1986)). On the basis of long-term temperature records (1995 - 1996 and 2004 - 2005) the most energetic modes in Lake Bourget (V1H1 and V2H1), were characterized (Bournet et al., 1996; Bournet 1996; Cuypers et al., 2006b). The V1H1 mode, a tilt of the thermocline along the North-South axis of the lake, displays a node in the middle of the lake. The V2H1 mode displays two vertical nodes at the depths of the upper and lower limits of the metalimnion. From one year to the next, the summer stratification and internal wave patterns are comparable. The periods of the dominant modes are about 24 hours for the V1H1 mode, 70-80 h for the V2H1 mode. Their amplitude goes up to $5 \mathrm{~m}$ (Bournet et al., 1996). 


\subsection{Proliphyc prototype and final systems}

The PROLIPHYC consortium is developing a real-time, autonomous monitoring station. According to the specifications, in the final buoy, the sensors will continuously measure temperature, chlorophyll- $a$ concentration and dissolved oxygen concentration at a single depth. Moreover, a profiling device will record daily profiles of the same parameters between the surface and the fixed position depth. Meteorological data will also be measured. Once in the water, the station will be installed easily, moored by a small motor-boat. Sensor maintenance will be facilitated by a freshwater-adapted protection against biofouling. An in situ biofouling protection of the sensors will be achieved daily by a chlorination device. At every 3 months, a local inspection will be required for servicing the whole system (platform, sensors, solar panels...). Measured data will be transmitted by GPRS to the laboratory where they will be automatically processed and eventually integrated into a short-term predictive model. When a phytoplankton bloom is forecasted, a warning will be sent to the lake managers by e-mail and/or mobile phone text messaging. At present, this final station is under development. Therefore, at the beginning of the project, a prototype station was developed in order to test and improve the system and the highfrequency data treatment. This prototype station displays all the same features, particularly the same sensors, as the final buoy but it does not include the antifoulant device, the GPRS data transmission neither the meteorological sensors. The autonomous prototype buoy was deployed on $11^{\text {th }}$ July 2007 at Point M $\left(45^{\circ} 42.725^{\prime} \mathrm{N}, 05^{\circ} 52.853^{\prime} \mathrm{E}\right)$ where water depth is around $90 \mathrm{~m}$ (Figure 1).

The sensors are located at a fixed depth $(15 \mathrm{~m})$. A CTD multiprobe (nke MPx) measures conductivity, temperature and pressure. An optode (Aanderaa 4175) measures dissolved oxygen. A fluorimeter (BBEMoldaenke FluoroProbe II) measures fluorescence at 5 wavelengths $(450,525,570,590$ and $610 \mathrm{~nm})$ so as to distinguish among phytoplankton classes. In this device, the excitation spectra of chlorophyll fluorescence is used to differentiate 4 main phytoplankton groups: diatoms and dinoflagellates, blue-green cyanobacteria, green algae and cryptophyta. Each group is characterised by a specific composition of accessory light-harvesting pigments, which can be associated to specific fingerprints (Beutler et al., 2002). In Lake Bourget, previous studies have shown that an additional, specific fingerprint can be assigned to the red, phycoerythrin containing $P$. rubescens (Leboulanger et al., 2002). Therefore, in this work, a specific fingerprint has been attributed to $P$. rubescens. Furthermore, the fluorimeter data are checked against cell counting and chlorophyll analysis of discrete field samples collected at the sensor depth and against samples of $P$. rubescens laboratory culture. This validation step is currently still ongoing but the fingerprint used in this work can already be considered reliable (Humbert and Escoffier, data not shown). In the following, only the fluorescence data associated to the Planktothrix rubescens fingerprint are used.

During the summer thermal stratification, the water column displays both a very high temperature gradient and a deep chlorophyll- $a$ maximum within the metalimnion as shown for example on $7^{\text {th }}$ August 2007 (Figure 2). The depth of $15 \mathrm{~m}$ was selected for the sensors, since maximal biomass of Planktothrix rubescens is likely to be observed.

The autonomy of the prototype is 3 months with a data acquisition at a 15-min time-step. Each month, the data are manually downloaded to a host computer from the buoy flash memory.

A pluri-annual time series has been recorded since $11^{\text {th }}$ July 2007 . It will be presented, analysed and thoroughly discussed in another paper. 


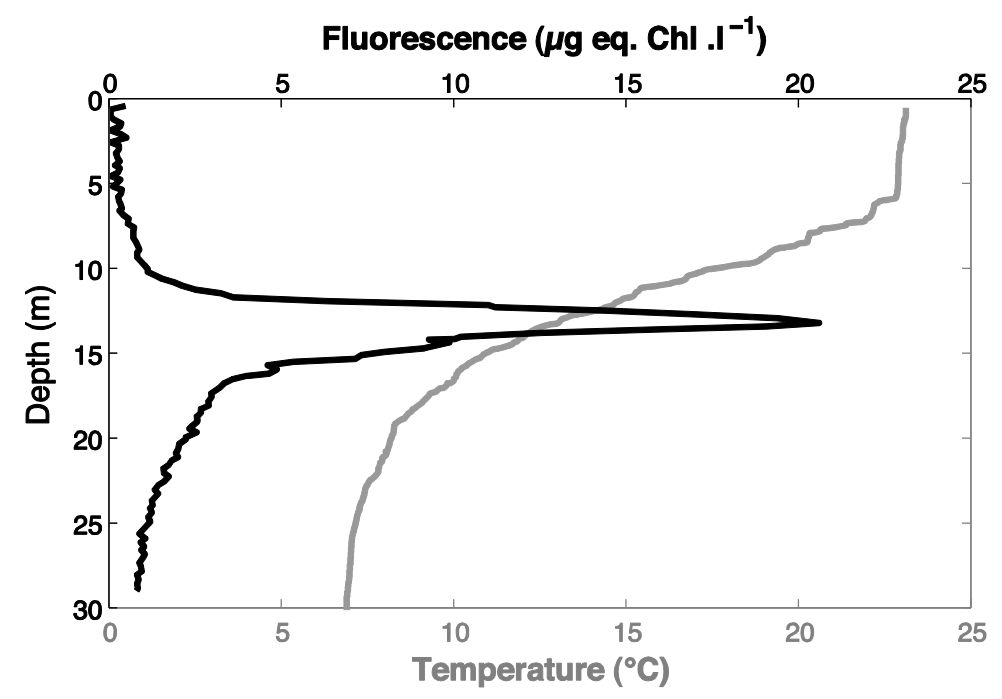

Figure 2: Temperature and fluorescence associated to Planktothrix rubescens at point M (07 August 2007 around 12:00 UT) (data CISALB, 2007).

\subsection{Time series treatment}

The objective of the data treatment is to derive indicators of phytoplankton biomass: the maximum fluorescence value in the vertical profile (fluorescence peak) and other associated parameters such as temperature, dissolved oxygen, conductivity, etc. One of the key points is the reliability of the time series measured at a single depth, for inferring the phytoplankton dynamics in the water column. Actually, in Lake Bourget, as in most stratified lakes, the water column displays very high gradients of temperature, oxygen and fluorescence (Figure 2). A slight motion of the water layers, for instance due to internal waves, will cause a great variation of the data recorded at a fixed depth. Therefore it is not easy to determine whether or not the fluorescence sensor actually measures the fluorescence peak nor to quantify its variation. The method developed to process the single-depth time series takes advantage of the internal wave pattern to assess the fluorescence peak during the thermal stratification.

\subsection{Conceptual description of the internal wave motion}

The internal waves result in the vertical oscillation of the water column in front of the fixed-depth sensors. A conceptual representation (Figure 3) of this phenomenon, limited to first order V1H1, is presented. It is based on the temperature and fluorescence vertical profiles measured on $7^{\text {th }}$ August 2007. The depth variation of temperature displays a monotonic decreasing gradient whereas the depth variation of fluorescence displays a maximum around $15 \mathrm{~m}$ depth (Figure 2). 


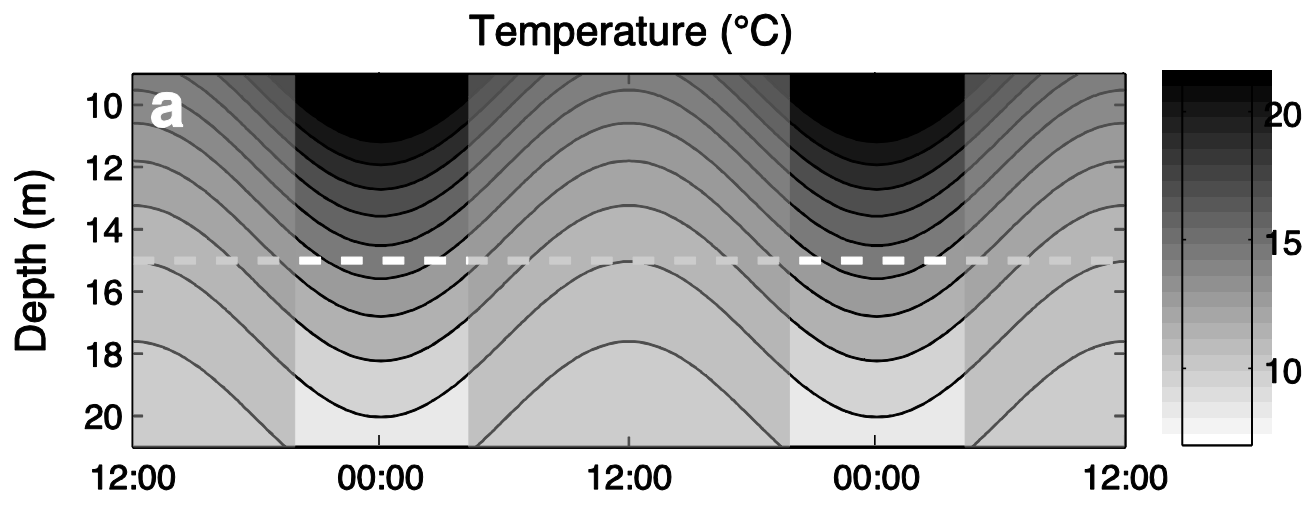

Fluorescence $\left(\mu \mathrm{g}\right.$ eq. $\left.\mathrm{Chl} . \mathrm{I}^{-1}\right)$

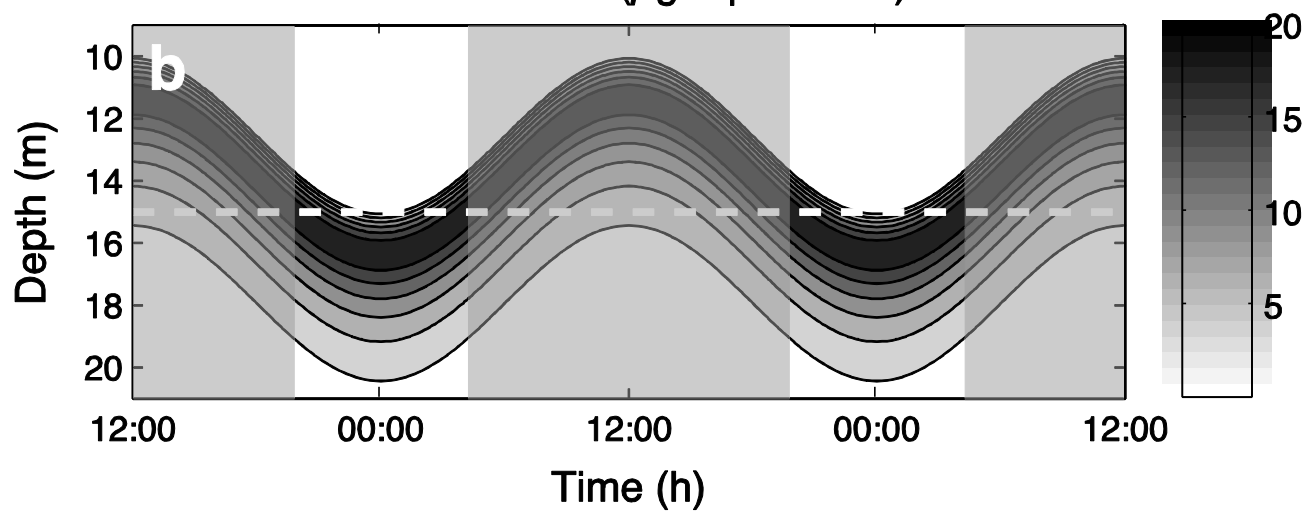

Figure 3: Conceptual representation of internal wave field (V1H1 mode, Period $=24 \mathrm{~h}$ ). Influence on: (a) the thermal structure of the water column based on the $7^{\text {th }}$ August situation; (b) the variation of the maximum fluorescence depth located in this case on the $13{ }^{\circ} \mathrm{C}$ isotherm. The white dashed line indicates the sensor position $(15 \mathrm{~m})$. Shaded areas indicate the stages when the fluorescence peak is located above the sensors.

Figure 4-a and b depicts the theoretical time evolution of temperature and fluorescence, due to a V1H1 internal wave of $24 \mathrm{~h}$-period, at a $15 \mathrm{~m}$ depth. From midnight to 5 a.m. and after 7 p.m., the fluorescence peak sinks below the sensors; fluorescence and temperature vary with time in phase opposition. After the fluorescence peak surges above the sensors, from 5 a.m. to 7 p.m., fluorescence $(F)$ and temperature (T) vary in phase. To track the position of the fluorescence peak relative to the sensors, the ratio $\Delta \mathrm{F} / \Delta \mathrm{T}$ between the fluorescence and temperature variations on each time step is computed (Figure 4-c). When $\Delta \mathrm{F} / \Delta \mathrm{T}>0$, the fluorescence peak is located above the sensors, when $\Delta \mathrm{F} / \Delta \mathrm{T}<0$, below the sensors. 

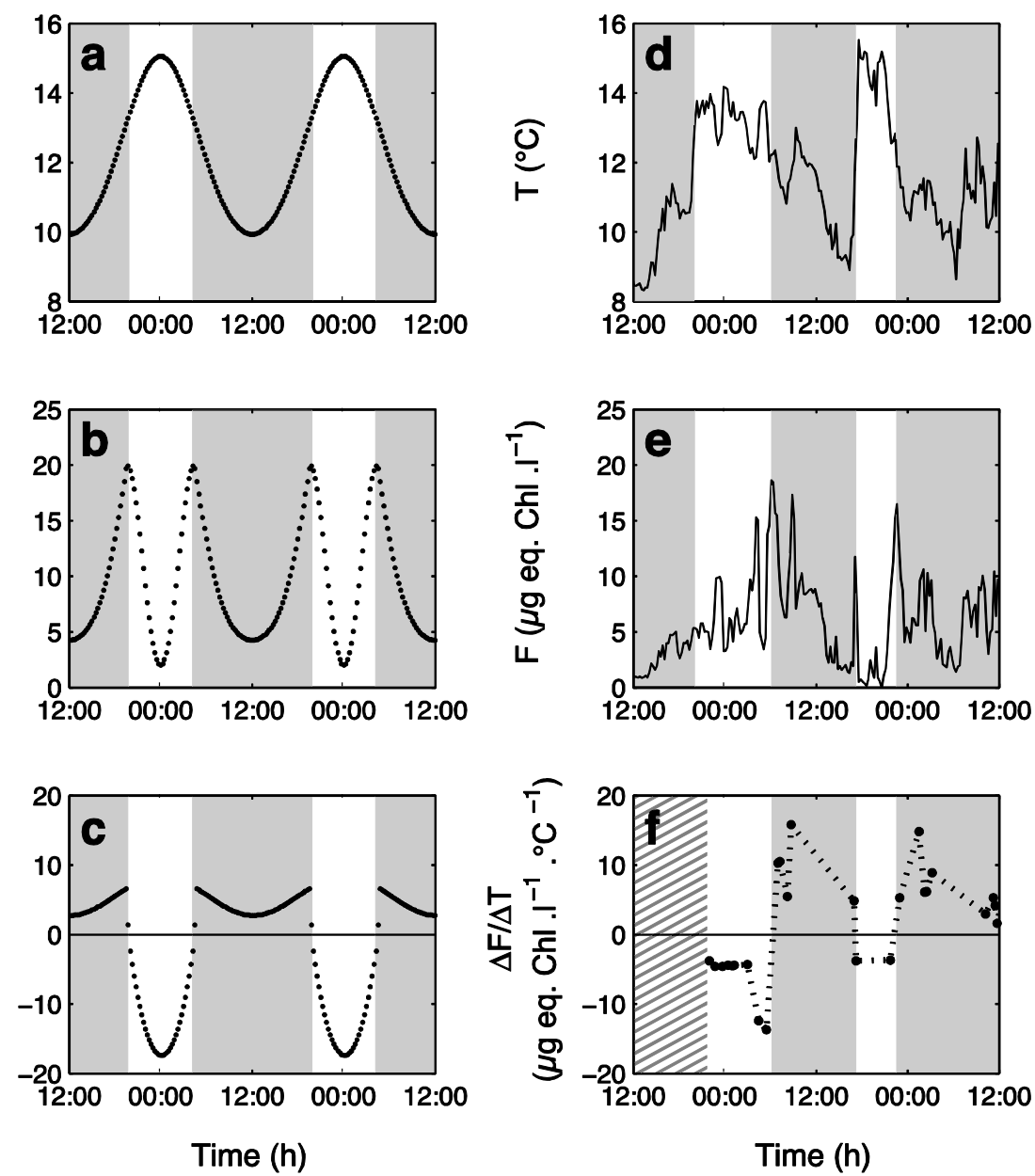

Figure 4: (a) temperature, (b) fluorescence and (c) corresponding $\Delta \mathrm{F} / \Delta \mathrm{T}$ ratio at $15 \mathrm{~m}$ in the conceptual representation; (d) temperature and (e) fluorescence measured by the sensors from 1 August to 03 August 2007 and (f) corresponding $\Delta \mathrm{F} / \Delta \mathrm{T}$ ratio. Shaded areas indicate the stages when the fluorescence peak is located above the sensors.

\subsection{Finding the actual fluorescence maximum values}

The method presented in the previous section enables us to validate whether the maximum fluorescence measured everyday can be regarded as the fluorescence peak. Temperature and fluorescence time series measured from $1^{\text {st }}$ to $3^{\text {rd }}$ August 2007 by the PROLIPHYC prototype are used to illustrate the functioning of the method (Figure 4-d and e).

At each time step, the ratio $\Delta \mathrm{F} / \Delta \mathrm{T}$ is computed (Figure 4-f). In order to overcome small scale measurement fluctuations, a threshold-based pre-treatment is applied to the raw data.

When the fluorescence peak drifts by the sensors during the internal wave period $(24 \mathrm{~h})$ the ratio $\Delta \mathrm{F} / \Delta \mathrm{T}$ changes sign. The maximum of the fluorescence during such a period can be regarded as the actual fluorescence peak value. If the peak fluorescence does not pass in front of the sensors, the ratio does not change sign, and the maximum measured fluorescence underestimates the fluorescence peak value. Therefore, the change in sign on an internal wave period provides an indicator that the fluorescence peak was detected. 


\subsection{Time evolution of the fluorescence peak characteristics}

In order to demonstrate the soundness of the method, the treatment of the daily maximum fluorescence was performed from $1^{\text {st }}$ to $15^{\text {th }}$ August 2007 (Figure 5-a). Daily information related to the phytoplankton dynamics and the sensor position can be extracted from the time series following the method previously described: the estimated fluorescence peak value, the related temperature (Figure 5-b) and the fraction of the day during which the fluorescence peak is above (resp. below) the sensors, computed as the time during which $\Delta \mathrm{F} / \Delta \mathrm{T}>0$ (resp. $\Delta \mathrm{F} / \Delta \mathrm{T}<0)$ (Figure 5-c).

On $12^{\text {th }}$ and $13^{\text {th }}$ August, the peak did not drift past the sensors and the maximum fluorescence measured underestimated the fluorescence peak value.
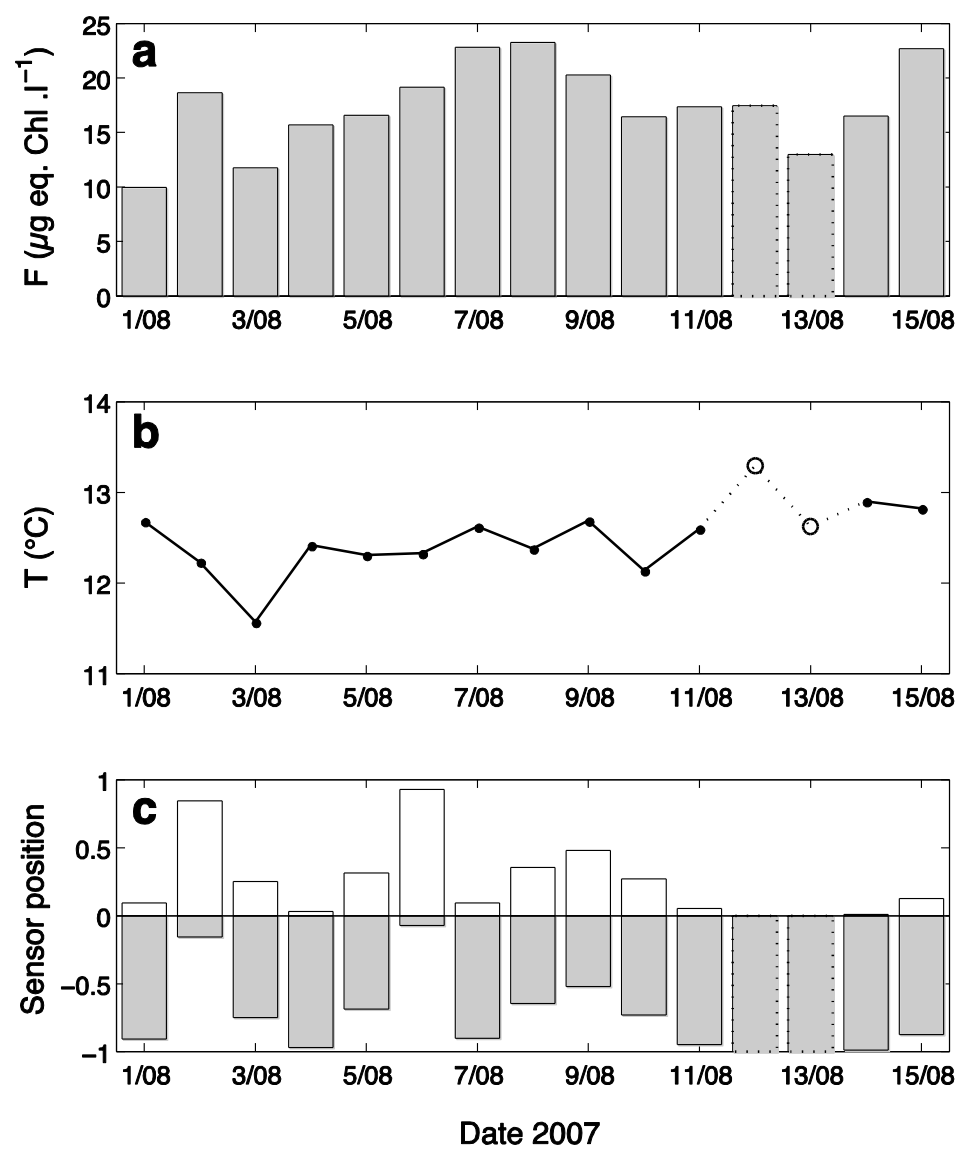

Figure 5: (a) Daily estimated fluorescence peak values; (b) Temperature related to the fluorescence peak; (c) Fraction of the day spent by the fluorescence peak above and below the sensors.

\subsection{Inference of the vertical fluorescence profile with a 1-D thermal model}

The vertical periodic water displacement due to internal waves also enables us to reconstruct the part of the vertical fluorescence profile scanned by the sensors. A consistent methodology has been developed and validated within the PROLIPHYC project to infer the spatialisation of the time series. Based on field observations, original data treatments provided a new concept named 'mean image', allowing new qualitative and quantitative interpretation of continuous measurements (Bensoussan et al., 2009; Bensoussan et al., 2008). This new comprehensive approach will be presented and analyzed in a forthcoming paper. The present paper introduces a method for spatialising the fixed-depth time series, using a thermal model for computing the temperature profiles. This model is a deterministic, one- 
dimensional vertical thermal model (Vinçon-Leite et al., 1989). It has been successfully applied on Lake Bourget for various meteorological conditions and over long time periods (Tassin and Vinçon-Leite, 1998; Vinçon-Leite et al., 1995b). It is based on the advective-dispersive equation of heat, integrated on the horizontal dimensions. The surface heat budget is described using a classical formulation of the radiative and convective fluxes (Henderson-Sellers, 1984), based on meteorological forcing variables (air temperature, humidity, cloudiness, wind velocity, air pressure). The vertical dispersion coefficient has a different formulation in the epilimnion and in the hypolimnion. The advective-dispersive equation is solved using a semi-implicit finite difference scheme with 1-m thick layers and a 3-h time step.

The daily mean temperature profiles in the water column are computed, disregarding the influence of internal waves. These profiles provide a one-to-one relation between temperature and depth (Figure 6-a). Measured temperature values can thus be linked to the depth at which they would be observed if there were no internal waves (Figure 6-b). Fluorescence can be plotted versus this equivalent depth. This treatment is performed for each internal wave period ( $24 \mathrm{~h}$ ) (Figure 6-c).
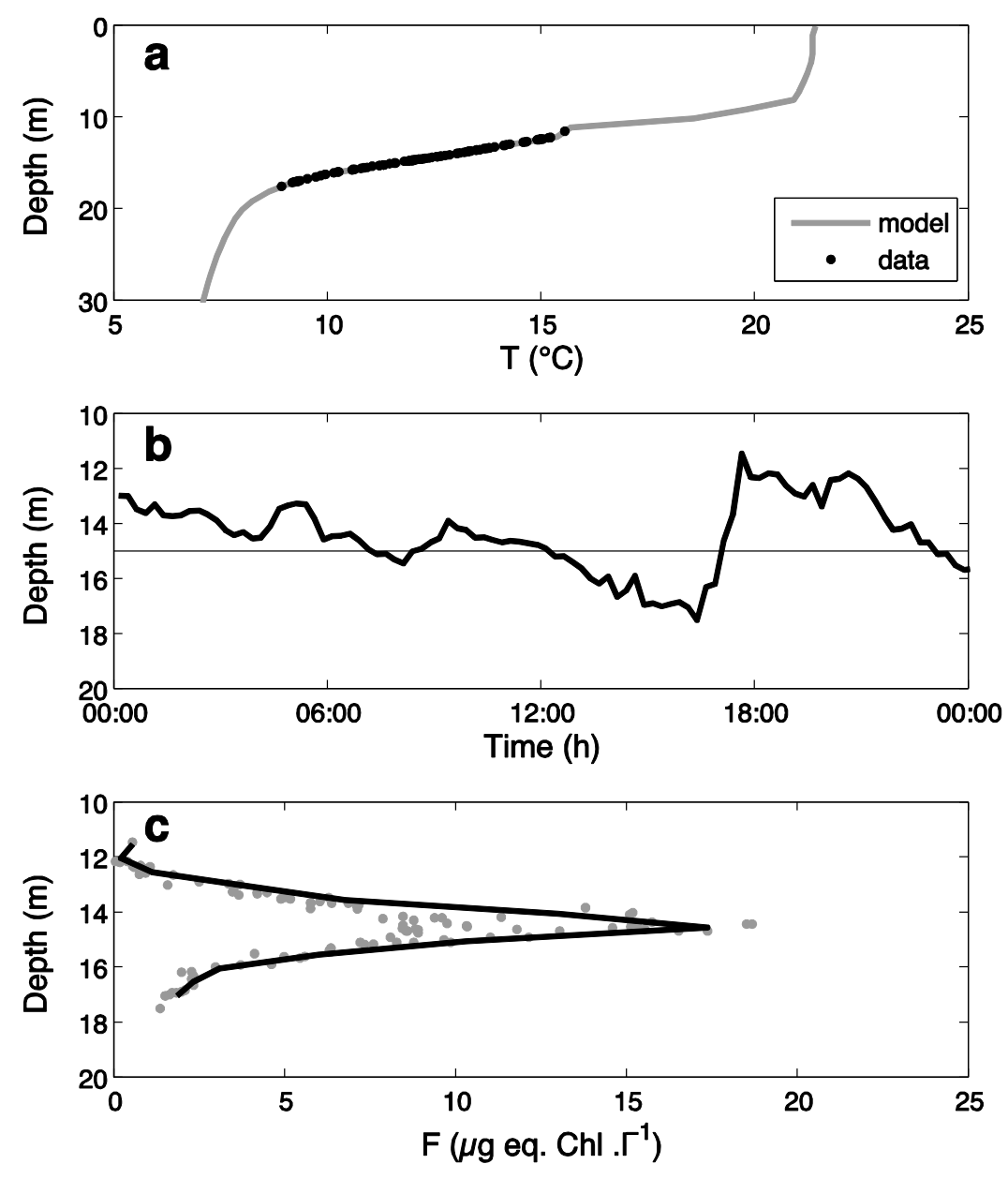

Figure 6: (a) Simulated temperature profile (grey line) and measured temperature (black dots) on 2nd August 2007; (b) Equivalent depth of measured temperature; (c) Corresponding fluorescence plotted versus equivalent depth (grey dots) and smoothed profile averaged on $0.5 \mathrm{~m}$ layers (black line). 
The daily update of the relation between temperature and depth yields the time evolution of the vertical distribution of fluorescence in the metalimnion (Figure 7). It can be noticed again that the fluorescence peak remains above the sensors on $12^{\text {th }}$ and $13^{\text {th }}$ August 2007.

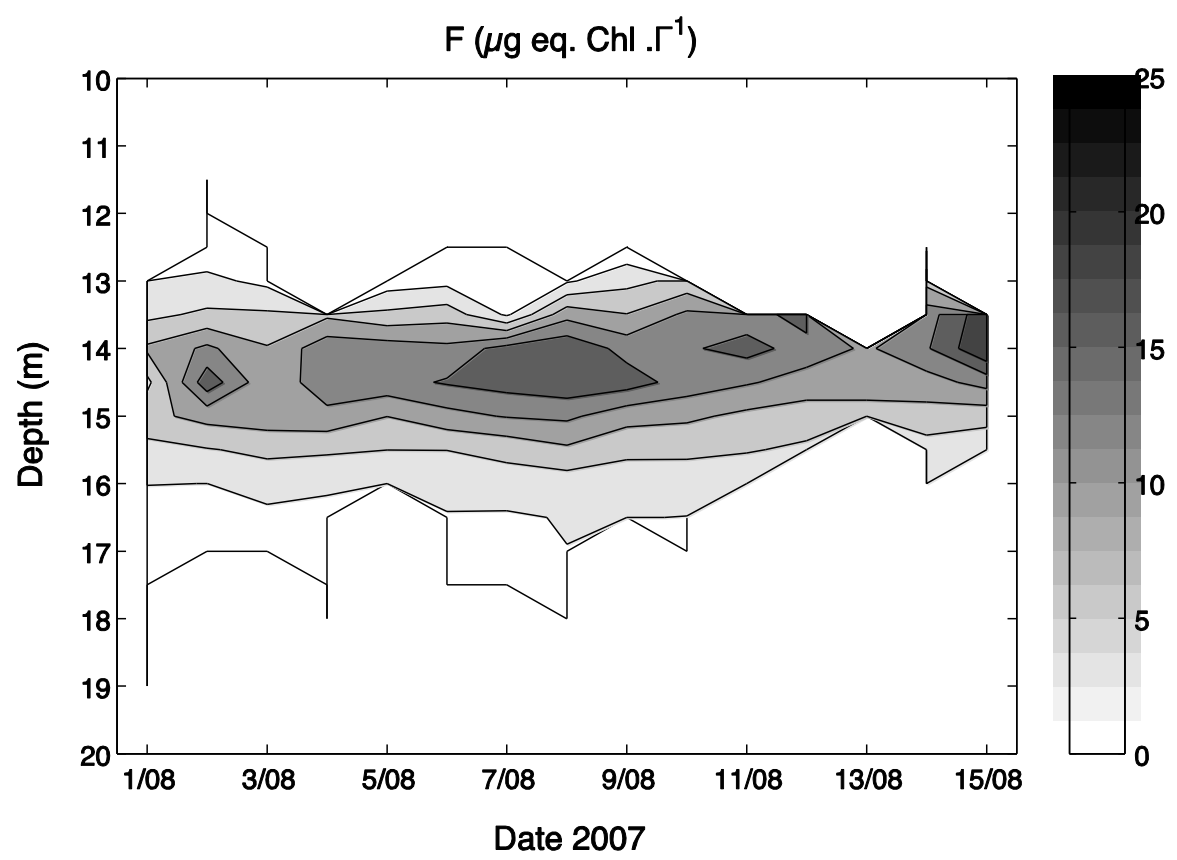

Figure 7: Fluorescence contour image inferred from the fluorescence and temperature time series and the 1D thermal model.

\section{Discussion}

The instrumented buoy, presented in this paper belongs to the simplest category of in situ highfrequency monitoring systems. It performs measurements at a single depth. The prototype does not include any profiling system, which reduces its cost and energy requirements and increases mechanical strength (no need of a winch and cable winder). Working with fixed-depth sensors also considerably simplifies data processing. Among the off-the-shelf sensors (conductivity, temperature, pressure, oxygen and fluorescence) embedded in the station, the spectrofluorimeter was chosen for its high performance so that it can distinguish among phytoplankton classes. The measurement features (frequency, depth, etc.) can be optimised for local applications.

The design of the prototype might appear a very doubtful option to assess phytoplankton dynamics in a stratified water column featuring strong, vertical biomass heterogeneity. It was therefore essential to establish if such a straightforward device was able to provide reliable information, from which comprehensive indicators could be derived for operational purposes.

The method described in this paper enables us to follow the dynamics of cyanobacterium Planktothrix rubescens which prevails in Lake Bourget. It first determines whether the sensor position is well located to detect the fluorescence peak along the vertical. Following the internal wave periodic motion, the fluorescence peak regularly drifts in front of the sensors, generally twice a day. For some dates, the sensors are clearly located within the fluorescence peak as it was the case during the first 10 days in August 2007 (Figure 5). On $12^{\text {th }}$ and $13^{\text {th }}$ August 2007, the sensors never detected the fluorescence peak which remained above the sensors; the recorded maximal values underestimated the maximum peak fluorescence (Figure 5).

It has been shown that the single-depth time series can yield the actual maximal values of the fluorescence, even if the sensors are not located at precise depth of the fluorescence peak. This requires 
that the distance between the sensors and the mean position of the fluorescence peak does not exceed the mean internal wave amplitude.

Moreover, the fluorescence peak can also be detected even if the fluorescence peak depth changes on a daily or weekly scale. When stratification is established at a stable depth in summer, the sensor position is to be set at the middle of the metalimnion after measuring a temperature profile.

When stratification is beginning in spring or ending in autumn, phytoplankton is more homogeneously spread in the euphotic zone and the amplitude of internal waves is greater than in summer. The singledepth monitoring system could still follow phytoplankton dynamics, but a different data treatment would be necessary.

Secondly, the fluorescence values of the peak and parameters recorded at the same time step can be extracted, such as temperature, dissolved oxygen, conductivity. Their seasonal and year-to-year evolution can be studied, as well as the relation of the fluorescence peak to additional environmental parameters (e.g. light, mixing, nutrients, etc.). Amongst other applications, phytoplankton dynamics can be modelled more efficiently, for example as part of a warning system: in the phytoplankton growth equation, the optimal temperature of the phytoplankton community in the metalimnion of the studied lake can be derived.

The metalimnetic spatial distribution of phytoplankton biomass can also be derived, using a 1D vertical thermal model and using the particular time evolution of the single-depth time series due to the internal wave motion. Furthermore, these reconstructed metalimnetic profiles can be used as initial conditions for predictive modelling embedded in a forecasting warning system. This outcome of the time series treatment can only be obtained when the thermal model has been previously calibrated and validated with an independent set of vertical profiles. Moreover, vertical profiles must be measured regularly in order to check the ongoing model simulation and adjust the parameter values if necessary. However, the 3-month autonomy of the prototype batteries requires regular maintenance, and this can be the opportunity to calibrate the sensors and to collect additional data.

Within the scope of the European Water Framework Directive, high-frequency measurements lead to valuable monitoring improvement. In a compromise between the number of lakes to monitor and sampling and analysis costs, the WFD sets a minimum measurement frequency of four times a year for physicochemical parameters, twice a year for phytoplankton, etc. (WFD, Annex V, § 1.3.4). ). This requirement can be consistently increased to twelve times a year. National authorities can increase these frequencies (e.g. Environmental Protection Agency, 2006; Ministère de l'Ecologie et du Développement Durable, 2006). The very low required frequencies permit to follow roughly the evolution of lakes, but extreme events of natural or anthropogenic origins will not be detected, which are particularly necessary to assess in a risk management framework. The monitoring will not enable the lake stakeholders to understand the functioning of the lakes so as to adapt their restoration strategy. It is insufficient for the calculation of most indicators of trophic status as defined for example by Organisation for Economic Co-operation and Development (1982) or Bricker et al. (2003). This is singularly true for phytoplankton. The WFD monitoring addresses two issues: (1) the assessment of phytoplankton biomass using chlorophyll- $a$ measurement as a proxy and (2) the record of the frequency, the composition and the intensity of phytoplankton blooms. It is assumed that phytoplankton biomass may be used as a proxy for net production and chlorophyll $a$ as an index of phytoplankton biomass (Painting et al., 2005). Considering the day-to-day variability of phytoplankton dynamics, it is clear that the sampling frequency generally performed in the WFD surveillance monitoring does not comply with its objectives (Carstensen, 2007), unlike a high-frequency monitoring system.

Moreover, high-frequency monitoring systems can also contribute to long-term surveillance programmes by recording the year-to-year variations of dynamics of phytoplankton succession, bloom temporal distribution, duration and intensity and associated parameters such as temperature, dissolved oxygen, conductivity. 
In lakes which require restoration, high-frequency monitoring would enable a better understanding of their functioning and more efficient programmes of measures could be defined.

Moreover, in both cases of operational and investigative monitoring programmes, routine sample monitoring does not always coincide with episodic discharges of pollutants. Real-time, instrumented buoys could help to pinpoint particular pollutant sources with a high degree of accuracy, for example during periods of wet weather.

Real-time monitoring systems are mandatory when a short-term response is needed, which is the case of cyanobacteria blooms. Bathers and drinking water producers need to be warned soon enough to close the beaches and to adapt the water production process. This is the ultimate aim of the PROLIPHYC project.

Additionally, the adaptation of the system in order to monitor phytoplankton in the sea could be studied. Sites where single-depth measurements could prove useful should exhibit strong and regular internal waves of known time period at depths at which phytoplankton grows. This should be possible in two types of sites: (i) when internal seiches dominate over internal tidal waves, which is the case in semienclosed bays or estuaries, as in Gullmar Fjord, Norway, where the pycnocline intersects a sill (Arneborg and Liljebladh 2001; Davies et al. 2009); this is close to the case of the large lake described in this paper, since the periods of internal wave modes are imposed by the bay or estuary geometry; (ii) when internal tidal waves are large: internal tides have semi-diurnal frequency and are either freely propagating waves, or more seldom partly standing waves, as in Mamala Bay, Hawaii (Alford et al. 2006); large semi-diurnal internal waves are common in oceans; large tides are also observed in particular sites of closed seas, like Gabes Bay, Tunisia (Sammari et al. 2006), even if the local internal wave climate apparently remains to be studied.

\section{Conclusion}

The data presented in this paper have been collected by a sensor-equipped buoy performing measurements at a single depth in the metalimnion of deep sub-alpine Lake Bourget. This simple, autonomous monitoring system coupled with an original method of data filtering (temperature and fluorescence) is able to derive a vertical representation of the phytoplankton biomass from high-frequency, single-depth measurements. It provides a powerful tool for supplying reliable data which can be further used to calculate operational indicators of lake status.

The method described, based on the use of the internal wave periodic motion, enables us to determine whether the sensor position is convenient to detect the fluorescence peak along the vertical. Secondly, the fluorescence values of the peak and parameters recorded at the same time step can be extracted, such as temperature, dissolved oxygen, conductivity. Their seasonal and year-to-year evolution can be studied, as well as the relation of the fluorescence peak to additional environmental parameters (e.g. light, mixing, nutrients etc.).

The autonomous buoy is also a part of an early warning system, for example aimed at signalling an HAB. In this case, when a forecasting model can be run, profiles reconstructed from the single-depth time series can be used as initial conditions for the predictive simulations.

Within the scope of the European Water Framework Directive's commitments, the system presented provides a valuable tool for operational monitoring (screening and verification of the impact of a programme of measures aimed at reducing the pressure on the water body). The system can also improve surveillance monitoring for the long-term changes involving events such as harmful algae blooms (HABs) which must be fully monitored to be characterized (duration and intensity of blooms). It could also help to meet the requirements of comparable legislation around the world like the US Clean Water Act or Australia's Water Act 2007 or the Canadian Environmental Protection Act. 


\section{Acknowledgements}

The Proliphyc project is funded by the ANR-PRECODD Programme. We wish to acknowledge Pascal Perney (INRA) for the logistic support and Yannis Cuypers (LOCEAN, Université Pierre et Marie Curie) for fruitful discussions. The authors also express their gratitude to Jean Sutcliff for the revision of the English text.

\section{References}

AFNOR. 2006. Water quality - Guidance standard on the enumeration of phytoplankton using inverted microscopy (Utermöhl technique). In: NF EN 15204.

Allan I, Vrana B, Greenwood R, Mills G, Roig B, Gonzalez C. 2006. A "toolbox" for biological and chemical monitoring requirements for the European Union's Water Framework Directive. Talanta 1st Swift-WFD workshop on validation of Robustness of sensors and bioassays for Screening Pollutants - 1st SWIFT-WFD 2004 69:302-322.

Anneville O, Gammeter S, Straile D. 2005. Phosphorus decrease and climate variability: mediators of synchrony in phytoplankton changes among European peri-alpine lakes. Freshwater Biology 50:17311746.

Anneville O, Ginot V, Druart J-C, Angeli N. 2002. Long-term study (1974-1998) of seasonal changes in the phytoplankton in Lake Geneva: a multi-table approach. J. Plankton Res. 24:993-1008.

Bensoussan N, Calzas M, Degres Y, Drezen C, Escoffier N, Freissinet C, Guillerm O, Humbert J, Jezequel D, Le Vu B, Paolini G, Prevot F, Quiblier C, Sarazin G, Tassin B, Vinçon-Leite B, Viollier E, Groleau A. 2009. Observing and integrating deep chlorophyll maximum of the metalimnetic cyanobacteria P.rubescens from single point measurements. In: ASLO Aquatic Science Meeting Abstracts. Nice, France. p 22.

Bensoussan N, Calzas M, Degres Y, Drezen C, Escoffier N, Freissinet C, Humbert J, Jezequel D, Le Vu B, Paolini G, Prevot F, Quiblier C, Sarazin G, Tassin B, Vinçon-Leite B, Viollier E, Groleau A. 2008. From in Situ Time Series to Mean Image: new Tools for Monitoring Harmful Algal Blooms. In: AGU fall meeting Geophysical research abstracts. San Francisco, USA.

Bergondo DL, Kester DR, Stoffel HE, Woods WL. 2005. Time-series observations during the low sub-surface oxygen events in Narragansett Bay during summer 2001. Marine Chemistry Special Issue in honor of Dana R. Kester 97:90-103.

Beutler, M., Wiltshire, K., Meyer, B., Moldaenke, C., Lüring, C., Meyerhöfer, M., Hansen, U.-P., and Dau, H. (2002). A fluorometric method for the differentiation of algal populations in vivo and in situ. Photosynthesis Research 72, 39-53.

Blain S, Guillou J, Treguer P, Woerther P, Delauney L, Follenfant E, Gontier O, Hamon M, Leilde B, Masson A, Tartu C, Vuillemin R. 2004. High frequency monitoring of the coastal marine environment using the MAREL buoy. Journal of Environmental Monitoring 6:569-575.

Bournet PE, Dartus, D., Tassin, B et Vinçon Leite B. 1996. Ondes internes du lac du Bourget: analyse des observations par des modèles linéaires. Revue des Sciences de l'Eau 9:247-266.

Briand J-F, Jacquet S, Flinois C, Avois-Jacquet C, Maisonnette C, Leberre B, Humbert J-F. 2005. Variations in the Microcystin Production of Planktothrix rubescens (Cyanobacteria) Assessed from a Four-Year Survey of Lac du Bourget (France) and from Laboratory Experiments. Microbial Ecology 50:418-428.

Bricker SB, Ferreira JG, Simas T. 2003. An integrated methodology for assessment of estuarine trophic status. Ecological Modelling 169:39-60. 
Carstensen J. 2007. Statistical principles for ecological status classification of Water Framework Directive monitoring data. Marine Pollution Bulletin Implementation of the Water Framework Directive in European marine waters 55:3-15.

CEREVE, GRETI, INRA, CelluleTechniquedulacduBourget. 1998. Analyse de l'évolution de la qualité des eaux du lac du Bourget (1995-1996). In. Chambéry: CISALB. p 310.

Chorus I, Bartram J, editors. 1999. Toxic Cyanobacteria in Water: a guide to their public health consequences, monitoring and management. Geneva: World Health Organization.

Cuypers Y, Vinçon-Leite B, Poulin M, Tassin B. 2006a. Non linear internal seiches degeneration in a in a deep sub-alpine. In: Proceedings of the $10^{\text {th }}$ european workshop on physical processes in natural waters. Granada, Spain.

Cuypers Y, Vinçon-Leite B, Poulin M., Bournet P-E, Tassin B. 2006b. Ondes internes et mélange turbulent dans le lac du Bourget. In: Colloque Lac du Bourget. Chambéry.

Cuypers Y, Vinçon-Leite B, Poulin M, Tassin B. Internal wave dynamics in a deep subalpine lake, from basin scale seiches to nonlinear high frequency waves. Submitted to Limnol Oceanogr

Dokulil MT, Teubner K. 2000. Cyanobacterial dominance in lakes. Hydrobiologia 438:1-12.

Dokulil MT, Teubner K. 2005. Do phytoplankton communities correctly track trophic changes? An assessment using directly measured and palaeolimnological data. Freshwater Biology 50:1594-1604.

Dorigo U, Fontvieille D, Humbert JF. 2006. Spatial variability in the abundance and composition of the free-living bacterioplankton community in the pelagic zone of Lake Bourget (France). Fems Microbiology Ecology 58:109-119.

Dur G, Schmitt F, Souissi S. 2007. Analysis of high frequency temperature time series in the Seine estuary from the Marel autonomous monitoring buoy. Hydrobiologia 588:59-68.

Dworak T, Gonzalez C, Laaser C, Interwies E. 2005. The need for new monitoring tools to implement the WFD. Environmental Science \& Policy Research \& Technology Integration in Support of the European Union Water Framework Directive 8:301-306.

Environmental Protection Agency. 2006. Water Framework Directive Monitoring Programme. Ireland.

Ernst B, Hoeger SJ, O'Brien E, Dietrich DR. 2006. Oral toxicity of the microcystin-containing cyanobacterium Planktothrix rubescens in European whitefish (Coregonus lavaretus). Aquatic Toxicology 79:31-40.

Ernst B, Hoeger SJ, O'Brien E, Dietrich DR. 2009. Abundance and toxicity of Planktothrix rubescens in the pre-alpine Lake Ammersee, Germany. Harmful Algae 8:329-342.

European Parliament and Council. 2000. Directive 2000/60/EC of the European Parliament and of the Council of 23 October 2000 establishing a framework for Community action in the field of water policy.

Ferreira J, Vale C, Soares C, Salas F, Stacey P, Bricker S, Silva M, Marques J. 2007. Monitoring of coastal and transitional waters under the E.U. Water Framework Directive. Environmental Monitoring and Assessment 135:195-216.

Feuillade J, Orand A. 1994. Studies on Lake Nantua. Lake surroundings and historical background. Studies on Lake Nantua (France). A Eutrophic Lake on the Way to Rehabilitation. Arch. Hydrobiol. Beih. Ergebn. Limnol. 42:1-16.

Garel, E., Nunes, S., Neto, J., Fernandes, R., Neves, R., Marques, J., and Ferreira, O. 2009. The autonomous Simpatico system for real-time continuous water-quality and current velocity monitoring: examples of application in three Portuguese estuaries. Geo-Marine Letters 29, 331-341

Gerdeaux D, Anneville O, Hefti D. 2006. Fishery changes during re-oligotrophication in 11 perialpine Swiss and French lakes over the past 30 years. Acta Oecologica 30:161-167.

Groleau A, Sarazin G, Vinçon-Leite B, Tassin B, Quiblier-Lloberas C. 2000. Tracing calcite precipitation with specific conductance in a hard water alpine lake (Lake Bourget). Water Research 34:4151-4160. 
Henderson-Sellers B. 1984. Engineering limnology. Boston: Pitman Advanced Pub. Program.

Holland DP, Walsby AE. 2008. Viability of the cyanobacterium Planktothrix rubescens in the cold and dark, related to over-winter survival and summer recruitment in Lake Zürich. European Journal of Phycology 43:179 - 184.

Hudnell, H. K. The state of U.S. freshwater harmful algal blooms assessments, policy and legislation. Toxicon In Press, Corrected Proof.

Humbert J-F, Paolini G, Leberre B. 2000. Monitoring a toxic cyanobacterial bloom in Lake Bourget (France) and its consequences for water quality. In: Proceedings of the $9^{\text {th }}$ International Conference on Harmful Algal Blooms. Hobart, Australia: G. Hallegraeff et al. p 496-499.

INSEE. 2008. Recensement de la population en France, http://www.insee.fr/fr/recensement/page_accueil_rp.htm.

Jann-Para G, Schwob I, Feuillade M. 2004. Occurrence of toxic Planktothrix rubescens blooms in lake Nantua, France. Toxicon 43:279-285.

Jeppesen, E., Søndergaard, M., Jensen, J.P., Havens, K.E., Anneville, O., Carvalho, L., Coveney, M.F., Deneke, R., Dokulil, M.T., Foy, B., Gerdeaux, D., Hampton, S.E., Hilt, S., Kangur, K., Köhler, J., Lammens, E.H.H.R., Lauridsen, T.L., Manca, M., Miracle, M.R., Moss, B., Nõges, P., Persson, G., Phillips, G., Portielje, R., Romo, S., Schelske, C.L., Straile, D., Tatrai, I., Willén, E., and Winder, M. (2005). Lake responses to reduced nutrient loading - an analysis of contemporary long-term data from 35 case studies. Freshwater Biology 50, 1747-1771.

Jones I, Maberly SC. 2008. Automatic in-lake monitoring in the English Lake District: The effect of lake size on stratification. International Association of Theoretical and Applied Limnology, Vol 30, Pt 1, Proceedings 30:70-72.

Kaiblinger, C., Anneville, O., Tadonleke, R., Rimet, F., Druart, J., Guillard, J., and Dokulil, M. (2009). Central European water quality indices applied to long-term data from peri-alpine lakes: test and possible improvements. Hydrobiologia 633, 67-74

Lee JHW, Hodgkiss IJ, Wong KTM, Lam IHY. 2005. Real time observations of coastal algal blooms by an early warning system. Estuarine Coastal and Shelf Science 65:172-190.

Lemmin U, Mortimer CH. 1986. Tests of an extension to internal seiches of Defant's procedure for determination of surface seiche characteristics in real lakes. Limnol. Oceanogr. 31:1207-1231.

Madgwick G, Jones ID, Thackeray SJ, Elliott JA, Miller HJ. 2006. Phytoplankton communities and antecedent conditions: high resolution sampling in Esthwaite Water. Freshwater Biology 51:1798-1810.

Mills DK, Laane R, Rees JM, van der Loeff MR, Suylen JM, Pearce DJ, Sivyer DB, Heins C, Platt K, Rawlinson M. 2003. Smartbuoy: A marine environmental monitoring buoy with a difference. In: Building the European Capacity in Operational Oceanography, Proceedings. p 311-316.

Ministère de l'Ecologie et du Développement Durable. 2006. Circulaire relative à la constitution et la mise en oeuvre du programme de surveillance pour les eaux douces de surface en application de la directive 2000/60/CE. France.

Oberhaus L, Groleau A, Quiblier-Lloberas C, Druart J-C, Vinçon-Leite B, Tassin B. 2003. Influence of physical factors on Cyanobacteria development in a deep subalpine lake (Lake Bourget). Journal de Recherche Océanographique 28.

Oberholster PJ, Botha A-M, Cloete TE. 2006. Toxic cyanobacterial blooms in a shallow, artificially mixed urban lake in Colorado, USA. Lakes and Reservoirs: Research and Management Vol. 11:111-123.

Organisation for Economic Co-operation and Development (OECD) 1982. Eutrophication of waters : monitoring, assessment and control. Paris.

Painting SJ, Devlin MJ, Rogers SI, Mills DK, Parker ER, Rees HL. 2005. Assessing the suitability of OSPAR EcoQOs for eutrophication vs ICES criteria for England and Wales. Marine Pollution Bulletin 50:1569-1584. 
Palethorpe B, Hayes-Gill B, Crowe J, Sumner M, Crout N, Foster M, Reid T, Benford S, Greenhalgh C, Laybourn-Parry J. 2004. Real-time physical data acquisition through a remote sensing platform on a polar lake. Limnology and Oceanography-Methods 2:191-201.

Paolini G. 2006. Le suivi de la qualité des eaux du lac du Bourget. In: Colloque "Autour du lac du Bourget". Chambéry, France.

Salmaso N, Morabito G, Buzzi F, Garibaldi L, Simona M, Mosello R. 2006. Phytoplankton as an Indicator of the Water Quality of the Deep Lakes South of the Alps. Hydrobiologia 563:167-187.

Sarmento H, Descy J-P. 2008. Use of marker pigments and functional groups for assessing the status of phytoplankton assemblages in lakes. Journal of Applied Phycology 20:1001-1011.

Tadonleke, R.D., Lazzarotto, J., Anneville, O., and Druart, J.C. (2009). Phytoplankton productivity increased in Lake Geneva despite phosphorus loading reduction. Journal of Plankton Research 31, 11791194.

Tassin B, Vinçon-Leite B. 1998. Forecasting of water quality in lakes: a predictive use of a onedimensional model. Application to lake Bourget (Savoie, France). Hydrobiologia 374:47-60.

Tilzer MM, Gaedke U, Schweizer A, Beese B, Wieser T. 1991. Interannual Variability of Phytoplankton Productivity and Related Parameters in Lake Constance - No Response to Decreased Phosphorus Loading. Journal of Plankton Research 13:755-777.

Vandenberghe, V., Goethals, P.L.M., Van Griensven, A., Meirlaen, J., De Pauw, N., Vanrolleghem, P., and Bauwens, W. 2005. Application of Automated Measurement Stations for Continuous Water Quality Monitoring of the Dender River in Flanders, Belgium. Environmental Monitoring and Assessment 108, 85-98.

Vinçon-Leite B, Mouchel JM, Tassin B. 1989. Modélisation de l'évolution thermique saisonnière du lac du Bourget (Savoie, France). Revue des Sciences de l'Eau 2:483-510.

Vinçon-Leite B, Tassin B, Druart J-C. 2002. Phytoplankton variability in Lake Bourget: Phytoplankton dynamics and meteorology Lakes \& Reservoirs: Research \& Management 7:93-102.

Vinçon-Leite B, Tassin B, Jaquet JM. 1995a. Contribution of Mathematical-Modeling to Lake Ecosystem Understanding - Lake Bourget (Savoy, France). Hydrobiologia 300:433-442.

Walsby AE, Ferdinand Schanz, Martin Schmid,. 2006. The Burgundy-blood phenomenon: a model of buoyancy change explains autumnal waterblooms by Planktothrix rubescens in Lake Zürich. New Phytologist 169:109-122.

Walsby AE, Schanz F. 2002. Light-dependent growth rate determines changes in the population of Planktothrix rubescens over the annual cycle in lake Zürich, Switzerland. New Phytologist 154:671-687. 